\title{
BK channels affect glucose homeostasis and cell viability of murine pancreatic beta cells
}

\author{
M. Düfer • Y. Neye • K. Hörth • P. Krippeit-Drews • \\ A. Hennige $\cdot H$. Widmer $\cdot H$. McClafferty $\cdot$ \\ M. J. Shipston • H.-U. Häring • P. Ruth • G. Drews
}

Received: 1 June 2010 / Accepted: 8 September 2010 /Published online: 28 October 2010

(C) Springer-Verlag 2010

\begin{abstract}
Aims/hypothesis Evidence is accumulating that $\mathrm{Ca}^{2+}$-regulated $\mathrm{K}^{+}\left(\mathrm{K}_{\mathrm{Ca}}\right)$ channels are important for beta cell function. We used BK channel knockout (BK-KO) mice to examine the role of these $\mathrm{K}_{\mathrm{Ca}}$ channels for glucose homeostasis, beta cell function and viability.

Methods Glucose and insulin tolerance were tested with male wild-type and BK-KO mice. BK channels were detected by single-cell RT-PCR, cytosolic $\mathrm{Ca}^{2+}$ concentration $\left(\left[\mathrm{Ca}^{2+}\right]_{\mathrm{c}}\right)$ by fura-2 fluorescence, and insulin secretion by radioimmunoassay. Electrophysiology was performed with the patch-clamp technique. Apoptosis was detected via caspase 3 or TUNEL assay.

Results BK channels were expressed in murine pancreatic beta cells. BK-KO mice were normoglycaemic but displayed
\end{abstract}

M. Düfer $\cdot$ Y. Neye $\cdot$ K. Hörth $\cdot$ P. Krippeit-Drews $\cdot$ P. Ruth $\cdot$

G. Drews $(\square)$

Institute of Pharmacy, Department of Pharmacology

and Toxicology, University of Tübingen,

Auf der Morgenstelle 8,

72076 Tübingen, Germany

e-mail: gisela.drews@uni-tuebingen.de

A. Hennige $\cdot$ H.-U. Häring

Department of Internal Medicine, Division of Endocrinology,

University of Tübingen,

Tübingen, Germany

H. Widmer

Division of Biological and Biomedical Science,

School of Life Sciences, Glasgow Caledonian University,

Glasgow, UK

H. McClafferty $\cdot$ M. J. Shipston

Centre for Integrative Physiology, College of Medicine

and Veterinary Medicine, University of Edinburgh,

Edinburgh, UK markedly impaired glucose tolerance. Genetic or pharmacological deletion of the BK channel reduced glucose-induced insulin secretion from isolated islets. BK-KO and BK channel inhibition (with iberiotoxin, $100 \mathrm{nmol} / \mathrm{l}$ ) broadened action potentials and abolished the after-hyperpolarisation in glucose-stimulated beta cells. However, BK-KO did not affect action potential frequency, the plateau potential at which action potentials start or glucose-induced elevation of $\left[\mathrm{Ca}^{2+}\right]_{\mathrm{c}}$. BK-KO had no direct influence on exocytosis. Importantly, in BK-KO islet cells the fraction of apoptotic cells and the rate of cell death induced by oxidative stress $\left(\mathrm{H}_{2} \mathrm{O}_{2}, 10-100 \mu \mathrm{mol} / \mathrm{l}\right)$ were significantly increased compared with wild-type controls. Similar effects were obtained with iberiotoxin. Determination of $\mathrm{H}_{2} \mathrm{O}_{2}$-induced $\mathrm{K}^{+}$currents revealed that $\mathrm{BK}$ channels contribute to the hyperpolarising $\mathrm{K}^{+}$current activated under conditions of oxidative stress.

Conclusions/interpretation Ablation or inhibition of BK channels impairs glucose homeostasis and insulin secretion by interfering with beta cell stimulus-secretion coupling. In addition, BK channels are part of a defence mechanism against apoptosis and oxidative stress.

Keywords Apoptosis - Beta cell · BK channel - Exocytosis · Iberiotoxin · Insulin · Stimulus-secretion coupling

$\begin{array}{ll}\text { Abbreviations } & \\ \text { BGC } & \text { Blood glucose concentration } \\ \text { BK-KO } & \text { BK channel knockout } \\ C_{\mathrm{m}} & \text { Membrane capacitance } \\ {\left[\mathrm{Ca}^{2+}\right]_{\mathrm{c}}} & \text { Cytosolic } \mathrm{Ca}^{2+} \text { concentration } \\ \mathrm{K}_{\mathrm{ATP}} \text { channel } & \text { ATP-dependent } \mathrm{K}^{+} \text {channel } \\ \mathrm{K}_{\mathrm{Ca}} \text { channel } & \mathrm{Ca}^{2+} \text {-activated } \mathrm{K}^{+} \text {channel } \\ \text { ROS } & \mathrm{Reactive} \mathrm{oxygen} \mathrm{species} \\ V_{\mathrm{m}} & \text { Membrane potential } \\ \text { WT } & \text { Wild-type }\end{array}$




\section{Introduction}

Nutrient-induced insulin release critically depends on the activity of ion channels and thus the extent of membrane depolarisation. The key event linking elevated glucose metabolism to alterations of electrical activity and eventually increased exocytosis is the closure of ATP-dependent $\mathrm{K}^{+}$ channels ( $\mathrm{K}_{\text {ATP }}$ channels) and subsequent opening of voltage-dependent $\mathrm{L}$-type $\mathrm{Ca}^{2+}$ channels. Besides $\mathrm{K}_{\text {ATP }}$ channels, the beta cells express a variety of other $\mathrm{K}^{+}$ channels that are regulated by voltage and/or by the cytosolic $\mathrm{Ca}^{2+}$ concentration $\left(\left[\mathrm{Ca}^{2+}\right]_{\mathrm{c}}\right)[1-3]$. The primary function of voltage-dependent $\mathrm{K}^{+}$channels $\left(\mathrm{K}_{\mathrm{v}}\right.$ channels), namely the repolarisation of action potentials, has been established for years [4]; however, the role of $\mathrm{Ca}^{2+}$-activated $\mathrm{K}^{+}$channels ( $\mathrm{K}_{\mathrm{Ca}}$ channels) is less clear. Currents through $\mathrm{K}_{\mathrm{Ca}}$ channels of large conductance (BK channels) were identified electrophysiologically in primary and clonal beta cells more than 20 years ago. Initially, these channels were suggested to play a role in the metabolic potentiation of insulin secretion and/ or regulation of the characteristic membrane potential oscillations [5, 6] but subsequent investigations did not confirm these assumptions. Several groups have shown that membrane potential oscillations are not affected by BK channel inhibitors $[7,8]$ and that the activation of $\mathrm{K}_{\mathrm{ATP}}$ channels, but not of $\mathrm{K}_{\mathrm{Ca}}$ channels, is a key event for induction of the electrically silent interburst phases $[9,10]$.

However, several recent observations have stimulated renewed interest in $\mathrm{K}_{\mathrm{Ca}}$ channels as regulators of beta cell function: (1) studies with two mouse models lacking sulfonylurea receptor 1 (SUR1)/inward rectifier $\mathrm{K}^{+}$channel Kir 6 (Kir6.2)-composed $\mathrm{K}_{\text {ATP }}$ channels (Surl [also known as Abcc8]- and Kir6.2 [also known as Kcnj11] knockout [KO] mice, respectively) have shown that regulated insulin release is possible via a $\mathrm{K}_{\mathrm{ATP}}$-channel-independent pathway which involves alterations of plasma membrane potential and $\left[\mathrm{Ca}^{2+}\right]_{\mathrm{c}}$ $[11,12]$; (2) the $\mathrm{K}^{+}$current that is activated during each burst phase of $\mathrm{Ca}^{2+}$ action potentials ( $\mathrm{K}_{\text {slow }}$ current) is not solely mediated by $\mathrm{K}_{\text {ATP }}$ channels but contains a sulfonylureainsensitive component that strongly depends on $\left[\mathrm{Ca}^{2+}\right]_{\mathrm{c}}[11$, 13]; (3) $\mathrm{K}_{\mathrm{Ca}}$ channels of small (SK1-3) and intermediate (SK4) conductance have been suggested to contribute to the $\mathrm{K}_{\text {slow }}$ current [3, 14]; and (4) knockout of $\mathrm{K}_{\mathrm{Ca}}$ channels of the SK4 type influences in vivo glucose homeostasis [3].

Interestingly, a recent study with beta cells from human non-diabetic donors suggests that the role of BK channels might be underestimated and provides evidence that inhibition of BK channels affects insulin secretion [15].

The generation of BK channel knockout (BK-KO) mice [16] by deletion of the Slol (also known as Kcnmal) gene now allows a detailed study of the contribution of these $\mathrm{K}^{+}$ channels to beta cell physiology and regulation of glucose homeostasis. Our data show that BK channels are involved in action potential repolarisation. We demonstrate, for the first time, that loss of BK channels impairs insulin secretion and glycaemic control. In addition, BK-KO increases the sensitivity of beta cells to oxidative stress via a direct effect on cell viability.

\section{Methods}

Animals, cell and islet preparation Experiments were performed with BK-KO and wild-type (WT) mice (in-house breeding). The principles of laboratory animal care were followed (National Institutes of Health publication number 85-23, revised 1985). Experiments were carried out according to German laws (Regierungspräsidium Stuttgart, approval number M 8/03). BK-KO mice were generated as previously described [16]. Mice were killed by $\mathrm{CO}_{2}$ and islets were isolated by collagenase digestion, dispersed in $\mathrm{Ca}^{2+}$-free medium and cultured for up to 4 days (RPMI 1640 medium, $11.1 \mathrm{mmol} / \mathrm{l}$ glucose, supplemented with $10 \%$ [vol./vol.] fetal calf serum, $100 \mathrm{U} / \mathrm{ml}$ penicillin and $100 \mu \mathrm{g} / \mathrm{ml}$ streptomycin).

Solutions and chemicals Bath solution for $\left[\mathrm{Ca}^{2+}\right]_{\mathrm{c}}$, membrane potential $\left(V_{\mathrm{m}}\right)$ and capacitance $\left(C_{\mathrm{m}}\right)$ measurements comprised: $140 \mathrm{mmol} / \mathrm{l} \mathrm{NaCl}, 5 \mathrm{mmol} / \mathrm{l} \mathrm{KCl}, 1.2 \mathrm{mmol} / 1 \mathrm{MgCl}_{2}$, $2.5 \mathrm{mmol} / 1 \mathrm{CaCl}_{2}, 15 \mathrm{mmol} / \mathrm{l}$ glucose and $10 \mathrm{mmol} / \mathrm{l} \mathrm{HEPES}$, $\mathrm{pH}$ 7.4. Pipette solution for perforated-patch recordings comprised: $10 \mathrm{mmol} / 1 \mathrm{KCl}, 10 \mathrm{mmol} / \mathrm{l} \mathrm{NaCl}, 70 \mathrm{mmol} /$ $1 \mathrm{~K}_{2} \mathrm{SO}_{4}, 4 \mathrm{mmol} / 1 \mathrm{MgCl}_{2}, 2 \mathrm{mmol} / 1 \mathrm{CaCl}_{2}, 10 \mathrm{mmol} / \mathrm{l} \mathrm{EGTA}$, $5 \mathrm{mmol} / \mathrm{l} \mathrm{HEPES}$, pH 7.15, and amphotericin B, $250 \mu \mathrm{g} / \mathrm{ml}$. Pipette solution for inside-out recordings comprised: $130 \mathrm{mmol} / 1 \mathrm{KCl}, 1.2 \mathrm{mmol} / 1 \mathrm{MgCl}_{2}, 2 \mathrm{mmol} / \mathrm{l} \mathrm{CaCl}$, $10 \mathrm{mmol} / \mathrm{l} \mathrm{EGTA}, 20 \mathrm{mmol} / \mathrm{l} \mathrm{HEPES}$, pH 7.4. Bath solution comprised: $130 \mathrm{mmol} / \mathrm{K} \mathrm{KCl}, 10 \mathrm{mmol} / \mathrm{l}$ EDTA, $20 \mathrm{mmol} /$ 1 HEPES, pH 7.2, with free $\mathrm{Ca}^{2+}$ adjusted to $10 \mu \mathrm{mol} / \mathrm{l}$ by $\mathrm{CaCl}_{2}$. Pipette solution for $C_{\mathrm{m}}$ determination comprised: $135 \mathrm{mmol} / \mathrm{l} \mathrm{K}$-gluconate, $10 \mathrm{mmol} / \mathrm{l} \mathrm{EGTA}, 4 \mathrm{mmol} / 1 \mathrm{MgCl}_{2}$, $5 \mathrm{mmol} / 1$ HEPES, $3 \mathrm{mmol} / 1 \mathrm{Na}_{2}$ ATP, $0.2 \mathrm{mmol} / \mathrm{l} \mathrm{cAMP}$, $\mathrm{pH} 7.2$, with free $\mathrm{Ca}^{2+}$ adjusted to $10 \mu \mathrm{mol} / 1$. Incubation medium for insulin secretion: $122 \mathrm{mmol} / \mathrm{l} \mathrm{NaCl}$, $4.8 \mathrm{mmol} / 1 \mathrm{KCl}, 2.5 \mathrm{mmol} / 1 \mathrm{CaCl}_{2}, 1.1 \mathrm{mmol} / 1 \mathrm{MgCl}_{2}$, $10 \mathrm{mmol} / \mathrm{l}$ HEPES and $0.5 \%(\mathrm{wt} / \mathrm{vol}$.) bovine serum albumin, $\mathrm{pH}$ 7.4.

Fura-2-acetoxymethyl ester (fura-2AM) was from Molecular Probes (Eugene, OR, USA) and iberiotoxin was from Bachem (Bubendorf, Switzerland). RPMI 1640 medium was from PromoCell (Heidelberg, Germany) and penicillin/streptomycin was from GIBCO/BRL (Karlsruhe, Germany). All other chemicals were purchased from Sigma (Deisenhofen, Germany) and Merck (Darmstadt, Germany).

Glucose and insulin tolerance tests In vivo experiments were performed with male BK-KO mice and WT littermates aged 12-19 weeks. Glucose ( $2 \mathrm{~g} / \mathrm{kg}$ body weight) or 
insulin (1 U/kg body weight) was injected intraperitoneally. Plasma glucose concentration was monitored for 120 (glucose tolerance) or 60 (insulin sensitivity) min. Mice were fasted for $16 \mathrm{~h}$ before testing glucose tolerance.

Measurement of intracellular free $\left[\mathrm{Ca}^{2+}\right]_{c}\left[\mathrm{Ca}^{2+}\right]_{c}$ was measured by the fura- 2 method using equipment and software from TILL photonics (Gräfelfing, Germany). Cells were identified as beta cells when $\left[\mathrm{Ca}^{2+}\right]_{c}$ was not decreased by $15 \mathrm{mmol} / \mathrm{l}$ glucose as described for alpha cells [17]. Cells were loaded with fura-2AM (5 $\mu \mathrm{mol} / \mathrm{l})$ for $30 \mathrm{~min}$ at $37^{\circ} \mathrm{C}$. $\left[\mathrm{Ca}^{2+}\right]_{\mathrm{c}}$ was calculated following an in vitro calibration with fura- $2 \mathrm{~K}^{+}$-salt [18].

Electrophysiology Patch pipettes were pulled from borosilicate glass capillaries (Clark, Pangbourne, UK). $V_{\mathrm{m}}$ was recorded at $32^{\circ} \mathrm{C}$ (EPC-9 patch-clamp amplifier; HEKA, Lambrecht, Germany). Cells were identified as beta cells when they were electrically silent with $0.5 \mathrm{mmol} / 1$ glucose but showed $\mathrm{Ca}^{2+}$ action potentials after switching to $15 \mathrm{mmol} / 1$ glucose. $\mathrm{K}^{+}$currents were elicited by $10 \mathrm{mV}$ voltage steps $(300 \mathrm{~ms})$ from a holding potential of $-70 \mathrm{mV} . C_{\mathrm{m}}$ was determined in the standard whole-cell configuration. To assay exocytosis an $830 \mathrm{~Hz}$ sine wave with a peak-to-peak amplitude of $30 \mathrm{mV}$ was applied to the cells $(-70 \mathrm{mV}$ holding potential). A train of eight cycles was applied to the cell every $5 \mathrm{~s}$. $C_{\mathrm{m}}$, membrane conductance and access conductance were derived from analysis of the sinusoidal membrane current at two orthogonal phase angles by the LockIn extension of the Pulse software ('sine+dc' protocol, HEKA). Data were analysed with 'Chart' software (ADInstruments, Spechbach, Germany).

Insulin secretion Batches of five islets were incubated for $60 \mathrm{~min}$ at $37^{\circ} \mathrm{C}$. Insulin was determined by radioimmunoassay using rat insulin (Linco Research, St Charles, MI, USA) as the standard.

Single cell PCR Cellular contents of single cells were aspirated into RNAse-free borosilicate patch-pipettes containing $7 \mu$ of RNAse-free water and were immediately transferred to an Eppendorf tube for cDNA synthesis using Sensiscript reverse transcriptase (Qiagen, Crawley, UK), RNasin ribonuclease inhibitor (Promega, Southampton, UK) and a mix of random and poly-dT primers in a final volume of $20 \mu \mathrm{l}$ at $37^{\circ} \mathrm{C}$ for $1 \mathrm{~h}$. For PCR analysis, $2-5 \mu \mathrm{l}$ of single-cell cDNA was used in a $20 \mu$ reaction using GoTaq DNA polymerase (Promega). Primers, insulin: forwards 5'-CAGCAAGCAGGTCATTGTTT-3', reverse 5'-CAGTAGTTCTCCAGCTGGTAGA-3'. Primers for the BK channel alpha subunit spanned the site of splicing $\mathrm{C} 2$ to detect BK channel splice variants: forwards 5'GTTTGTGAGCTGTGTTTTGTG-3', reverse 5'-CTACGGT
TACCAGGTGGTCATGT-3'. Amplicons were run on a $1.5 \%$ (wt/vol.) agarose gel and visualised using Sybr Safe.

Determination of apoptotic islet cells Islet cells were seeded on glass cover slips and cultured in RPMI 1640 medium for $24 \mathrm{~h}$. Apoptosis was determined by active caspase 3 (NucView assay, Biotium, Hayward, CA, USA) or TUNEL staining. In each condition, a minimum of 1,000 cells from three to four different isolations was counted. Growth medium was removed and $40 \mu$ l DEVD-NucView 488 caspase 3 substrate was added. Upon enzymatic cleavage of the substrate, the released DNA dye migrates to the cell nucleus where it binds to the DNA resulting in a highly fluorescent complex. For TUNEL labelling, pancreatic islet cells were fixed with 3\% (wt/vol.) paraformaldehyde at $20-25^{\circ} \mathrm{C}$ for $1 \mathrm{~h}$. After rinsing with PBS, beta cells were permeabilised for $2 \mathrm{~min}$ on ice [0.1\% [wt/vol.] Triton$\mathrm{X}$ and sodium citrate solution). Each sample was covered with $50 \mu \mathrm{l}$ TUNEL reaction mixture and incubated in a humidified atmosphere for $1 \mathrm{~h}$ at $37^{\circ} \mathrm{C}$ in the dark. TUNEL-positive cells were detected by fluorescein staining $(480 \mathrm{~nm})$ and the number of total cells was visualised with Hoechst 3342.

Presentation of results At least three different cell preparations were used for each series. Means \pm SEM are given in the text. Statistical significance of differences was assessed by a one-sample or Student's $t$ test for paired values; multiple comparisons were made by ANOVA followed by Student-Newman-Keuls test. For action potential characteristics five action potentials of each experiment were averaged. Peak values were set to $t=0 \mathrm{~ms}$ and data were analysed every $50 \mathrm{~ms}$ within the preceding and following $200 \mathrm{~ms}$. A $p$ value of less than 0.05 was considered significant.

\section{Results}

Activity and expression of BK channels in pancreatic islet cells In excised inside-out patches of isolated WT islet cells unitary $\mathrm{K}^{+}$current amplitudes of $11.0 \pm 0.8 \mathrm{pA}$ (holding potential of $-50 \mathrm{mV}$, symmetrical $\mathrm{K}^{+}$concentration), with an open probability (Po) of $0.012 \pm 0.002 \quad(n=5)$, were detected in 16 out of 43 patches (Fig. 1a). The current was $\mathrm{Ca}^{2+}$ dependent and the cord conductance calculated from the single channel $I / V$ curve was $238 \pm 8 \mathrm{pS}$ ( $n=5$, Fig. $1 \mathrm{c}$ ). As a $\mathrm{Ca}^{2+}$-regulated $\mathrm{K}^{+}$current with similar properties was absent in excised patches of beta cells obtained from BKKO mice ( $n=30$, Fig. 1b) the single channel currents were attributed to BK channels. The expression of BK channel pore-forming alpha subunits in pancreatic islet cells was further characterised by single-cell PCR experiments 
a

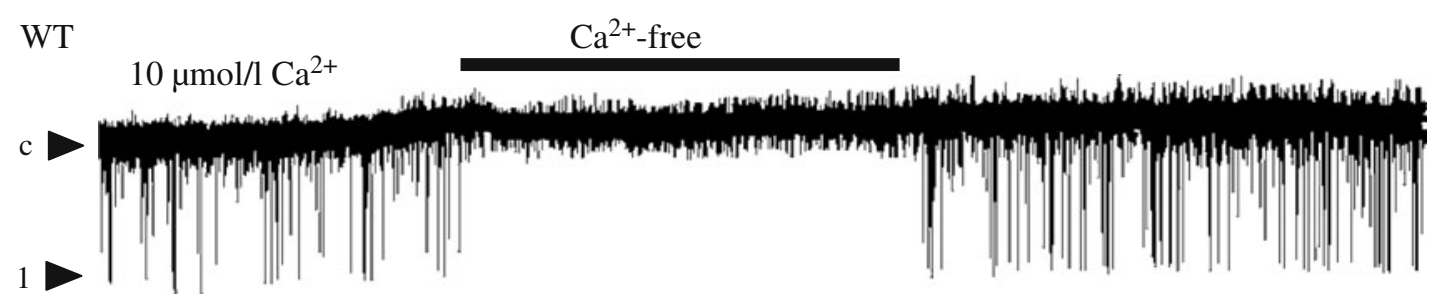

b

$\mathrm{BK}-\mathrm{KO}$
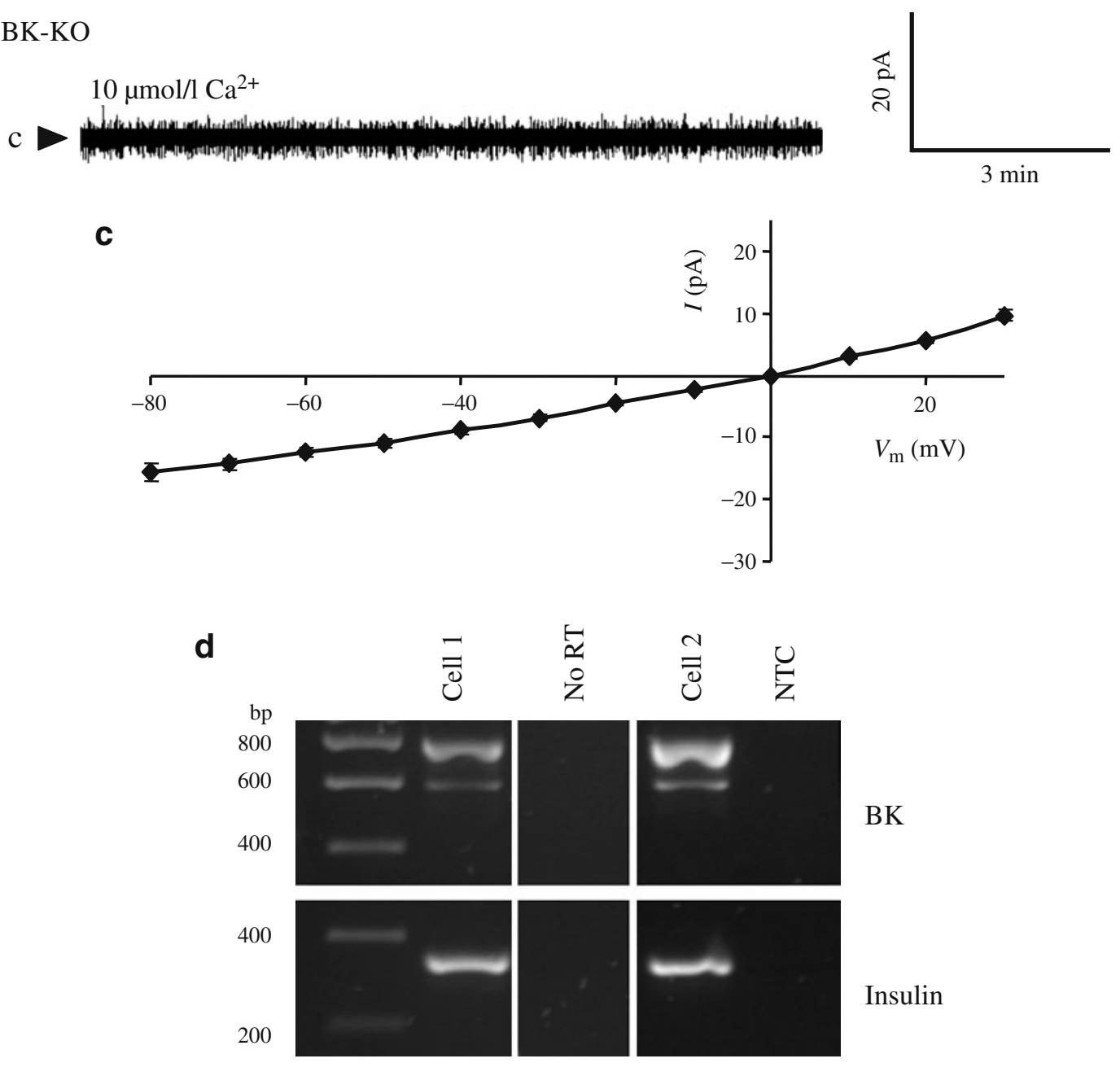

Fig. 1 BK channel activity and expression in pancreatic islet cells. a Single channel currents were recorded at a holding potential of $-50 \mathrm{mV}$ in inside-out patches of WT islet cells. For the time indicated by the horizontal bar, the BK-channel-positive patches were perifused with $\mathrm{Ca}^{2+}$-free solution. One representative experiment out of 16 single channel recordings is shown. c represents the closed state, 1 represents the open state of one BK channel. b Single channel currents were recorded at a holding potential of $-50 \mathrm{mV}$ in inside-out patches

(Fig. 1d). mRNAs of two BK channel alpha subunit splice variants (Zero and Strex) were detected in insulin-positive islet cells, indicating BK channel expression in beta cells.

BK-KO mice display reduced insulin secretion and impaired glucose tolerance To elucidate whether BK chan-

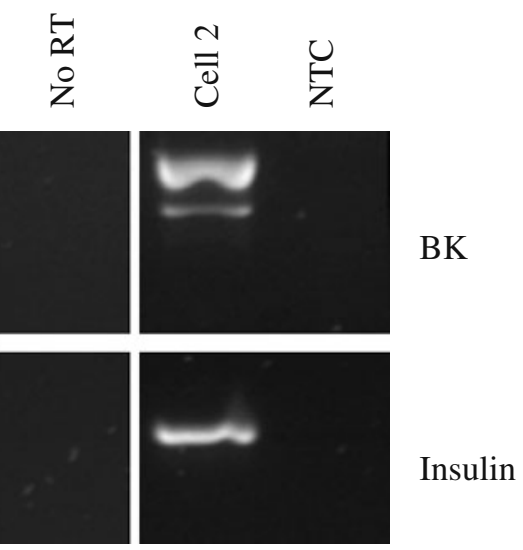

of BK-KO islet cells. One representative experiment out of 30 single channel recordings is shown. c $I / V$ curve for single channel currents recorded from inside-out patches of WT beta cells at voltages ranging from -80 to $+30 \mathrm{mV}$. d mRNA of the BK channel splice variants Zero ( $\sim 600 \mathrm{bp})$ and Strex ( $\sim 800 \mathrm{bp})$ were detected by RT-PCR performed with cytosol derived from single islet cells. Cell 1 and 2 are examples of insulin-positive cells. NTC, non-template control; No RT, control without enzyme

nels are involved in regulation of insulin secretion, the secretory response to glucose was determined in static incubations of isolated WT and BK-KO islets (Fig. 2a). Insulin release was similar in WT and $\mathrm{KO}$ islets under resting conditions ( $3 \mathrm{mmol} / \mathrm{l}$ glucose) and at glucose concentrations lower than $10 \mathrm{mmol} / \mathrm{l}$. However, stimulation 
a

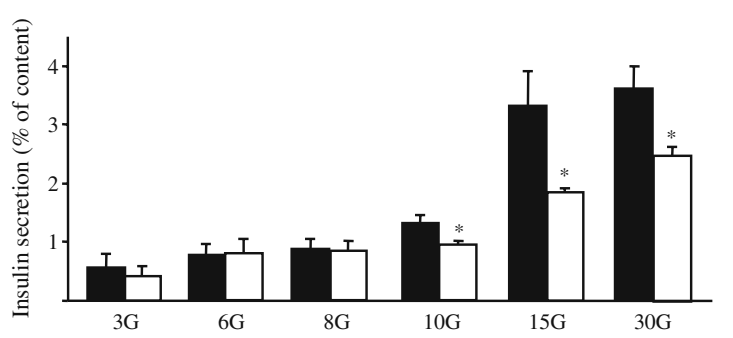

b

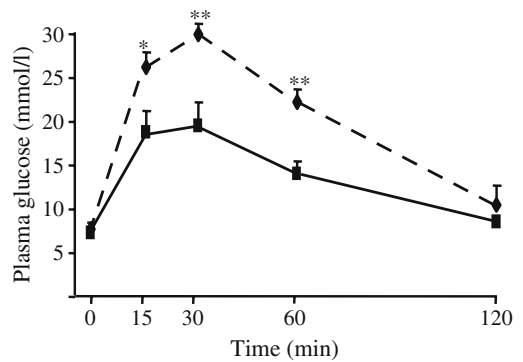

C

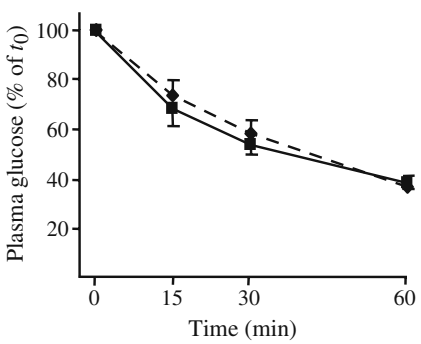

Fig. 2 Effect of BK-KO on insulin secretion, glucose tolerance and insulin sensitivity. a Isolated islets were incubated with different glucose concentrations for $60 \mathrm{~min}$. In the presence of 10, 15 and $30 \mathrm{mmol} / \mathrm{l}$ glucose, insulin release from BK-KO islets was significantly lower than from WT islets $(n=4$ different preparations per genotype). b BGC of male WT and BK-KO littermates was monitored before and for $2 \mathrm{~h}$ after i.p. injection of glucose ( $2 \mathrm{~g} / \mathrm{kg}$ body weight). c For determination of insulin sensitivity, blood glucose was followed before and for $1 \mathrm{~h}$ after i.p. injection of insulin ( $1 \mathrm{U} / \mathrm{kg}$ body weight). Glucose tolerance of BK-KO mice was markedly impaired compared with WT mice $(n=6 \mathrm{BK}-\mathrm{KO}$ and $n=8 \mathrm{C} 57 \mathrm{~B} 16$ WT littermates, respectively), whereas insulin sensitivity was unaffected ( $n=6 \mathrm{BK}-\mathrm{KO}$ and $n=5$ WT littermates, respectively). ${ }^{*} p \leq 0.05,{ }^{* *} p \leq 0.01$; black bars and solid lines, WT mice; white bars and dashed lines, BK-KO mice

Stimulus-secretion coupling in BK-KO beta cells The observation that glucose-stimulated insulin release was reduced in $\mathrm{BK}-\mathrm{KO}$ islets whereas $\mathrm{K}^{+}$-induced secretion was unaffected suggests that loss of BK channel function may impair the coupling of glucose metabolism, electrical activity and $\mathrm{Ca}^{2+}$ influx. Consequently, we tested whether the stimulus-secretion cascade was altered in BK channeldeficient beta cells.

The key event linking glucose metabolism to exocytosis is the increase in $\left[\mathrm{Ca}^{2+}\right]_{c}$ induced by opening of L-type $\mathrm{Ca}^{2+}$ channels subsequent to membrane depolarisation. Therefore, we investigated whether ablation of BK channels affected $\left[\mathrm{Ca}^{2+}\right]_{\mathrm{c}}$. In WT beta cells the increase in glucose concentration from 0.5 to $15 \mathrm{mmol} / 1$ led to an initial drop of $\left[\mathrm{Ca}^{2+}\right]_{\mathrm{c}}$ due to activation of ATP-dependent $\mathrm{Ca}^{2+}$ pumps. With the opening of L-type $\mathrm{Ca}^{2+}$ channels $\left[\mathrm{Ca}^{2+}\right]_{\mathrm{c}}$ was elevated to a plateau and, finally, characteristic oscillations occurred $(n=12)$. This pattern of activity likewise existed in BK-KO beta cells $(n=14$, Fig. 3). There was no difference in the area under the curve for the first rise of $\left[\mathrm{Ca}^{2+}\right]_{\mathrm{c}}$ after elevating glucose from 0.5 to $15 \mathrm{mmol} / \mathrm{l}$ (Fig. 3d-f) or in the frequency of $\mathrm{Ca}^{2+}$ oscillations (Fig. $3 \mathrm{~g}$ ). The lag time between the elevation of glucose concentration and the rise of $\left[\mathrm{Ca}^{2+}\right]_{\mathrm{c}}$ (WT $140 \pm$ $15 \mathrm{~s}[n=12]$ vs BK-KO $146 \pm 13$ s $[n=13])$ was also similar for both genotypes.

Compatible with the data obtained for $\left[\mathrm{Ca}^{2+}\right]_{\mathrm{c}}$ neither the resting membrane potential in $0.5 \mathrm{mmol} / \mathrm{l}$ glucose nor the plateau potential (potential from which $\mathrm{Ca}^{2+}$ action potentials start) with $15 \mathrm{mmol} / 1$ glucose were significantly altered by BK-KO (Fig. 4a,b). On average, the resting membrane potential was $-69 \pm 1 \mathrm{mV}(n=10)$ in BK-KO beta cells and $-70 \pm 1 \mathrm{mV}(n=12)$ in WT beta cells. The plateau potential was $-47 \pm 1 \mathrm{mV}(n=12)$ and $-48 \pm 1 \mathrm{mV}(n=12)$, respectively. Interestingly, $\mathrm{BK}-\mathrm{KO}$ influenced the shape of $\mathrm{Ca}^{2+}$ glucose homeostasis in vivo. 

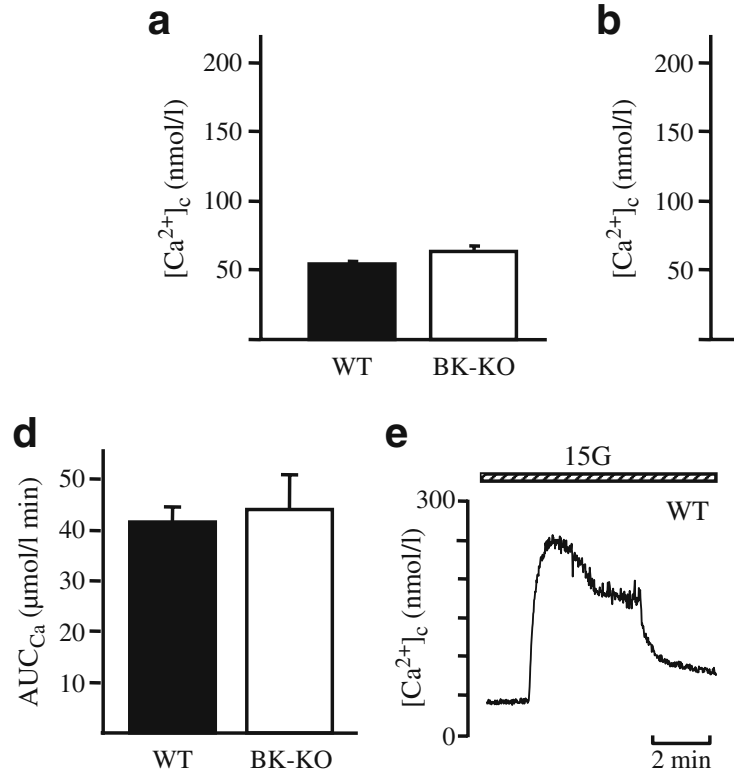

Fig. 3 Influence of BK-KO on $\left[\mathrm{Ca}^{2+}\right]_{\mathrm{c}}$. a BK-KO does not affect basal $\left[\mathrm{Ca}^{2+}\right]_{\mathrm{c}}$ in $0.5 \mathrm{mmol} / 1$ glucose ( $n=14$ for both genotypes). b-d After switching to $15 \mathrm{mmol} / \mathrm{l}$ glucose there was no difference in the first $\mathrm{Ca}^{2+}$ peak in BK-KO vs WT cells in terms of: (b) the initial decrease ( $n=14$ for both genotypes); (c) the peak $\left[\mathrm{Ca}^{2+}\right]_{\mathrm{c}}$ (WT $n=12$;

action potentials. In BK-KO beta cells, the spike duration of action potentials at half-maximum amplitude was significantly increased from $12 \pm 1 \mathrm{~ms}(\mathrm{WT}, n=12)$ to $18 \pm 1 \mathrm{~ms}$ (BK-KO, $n=12, p \leq 0.001)$ and the typical afterhyperpolarisation was completely abolished (Fig. 4c). Identical changes could be induced in WT cells by addition of $100 \mathrm{nmol} / \mathrm{l}$ of the specific BK channel blocker iberiotoxin $(n=4$, not shown), indicating that BK channels are involved in action potential repolarisation. However, BK-KO did not affect action potential frequency (WT $58 \pm 10 \mathrm{~min}^{-1}[n=12]$, BK-KO $62 \pm 16 \min ^{-1}[n=10]$ ) or action potential amplitude (WT $60 \pm 2 \mathrm{mV}$; BK-KO $63 \pm 3 \mathrm{mV}[n=12]$ ).

Furthermore, we examined whether BK channels directly interact with the exocytotic machinery. The standard wholecell configuration was used to measure $C_{\mathrm{m}}$ and cells were dialysed with pipette solution adjusted to $10 \mu \mathrm{mol} / \mathrm{l}$ free $\mathrm{Ca}^{2+}$. Figure $4 \mathrm{~d}$ shows that the rate of change in $C_{\mathrm{m}}$ in response to $10 \mu \mathrm{mol} / 1 \mathrm{Ca}^{2+}$ was not significantly different between WT $(n=14)$ and BK-KO $(n=13)$ beta cells. To exclude that BK-KO has any effect on cell size, whole-cell capacitance was determined in each experiment (WT 9.7 \pm $0.5 \mathrm{pF}[n=13]$; BK-KO 9.6 $\pm 0.5 \mathrm{pF}[n=14])$ and exocytosis was normalised to these values.

BK channels affect beta cell viability As BK channels have been described to be involved in regulation of cell survival [19] we determined apoptotic cell death in WT and BK-KO cells cultured in $11.1 \mathrm{mmol} / 1$ glucose. Importantly, the fraction of apoptotic islet cells was more than doubled in
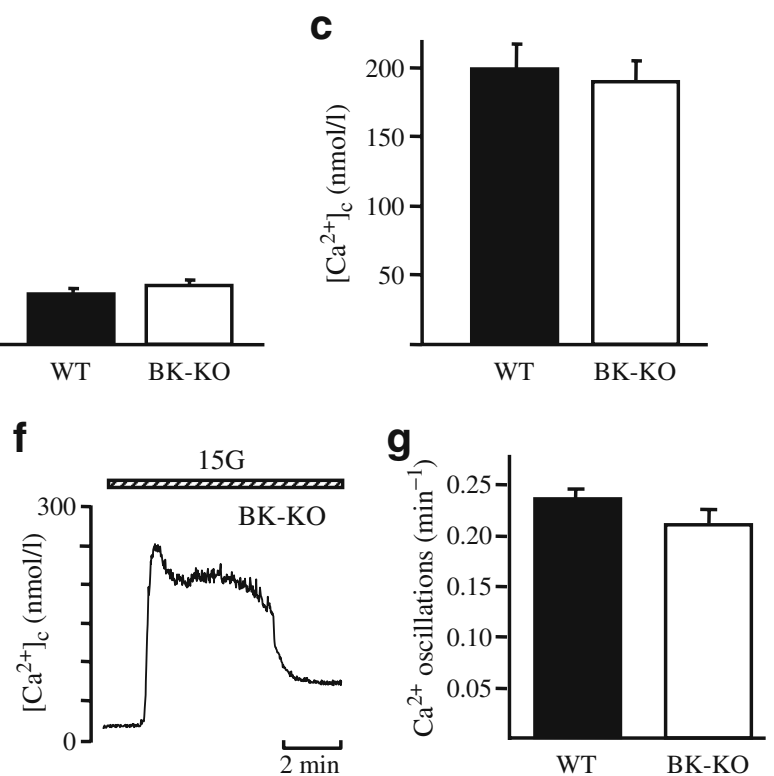

BK-KO $n=15$ ); or (d) the area under the curve (WT $n=12$; BK-KO $n=13$ ). e, f Representative experiments for (e) WT cells, and (f) BKKO cells. g A summary of the analysis of the frequency of $\mathrm{Ca}^{2+}$ oscillations in the presence of $15 \mathrm{mmol} / 1$ glucose (WT $n=51$; BK-KO $n=23$ )

BK-KO vs WT mice (Fig. 4e). In agreement with the increased rate of cell death in BK-KO islets, treatment of WT cells with iberiotoxin (100 nmol/l, $36 \mathrm{~h})$ elevated apoptosis by $\sim 50 \%$ ( $n=3, p \leq 0.05$, not shown).

This suggests that, in addition to the modulation of electrical activity, BK channels are involved in pathways determining apoptotic cell death.

Role of BK channels in response to oxidative stress As BK channel activity is linked to cell death we studied the role of these channels in oxidant-induced $\mathrm{K}^{+}$channel activation and apoptosis. In previous studies we demonstrated that stimulus-secretion coupling of pancreatic beta cells is severely affected by oxidative stress [20-22]. Reactive oxygen species (ROS) such as $\mathrm{H}_{2} \mathrm{O}_{2}$ hyperpolarise the plasma membrane via activation of $\mathrm{K}_{\mathrm{ATP}}$ channels, thereby inhibiting insulin secretion. As we could also show that abrogation of electrical activity coincides with a drastic increase in $\left[\mathrm{Ca}^{2+}\right]_{\mathrm{c}}[20]$, activation of $\mathrm{K}_{\mathrm{Ca}}$ channels might also contribute to the hyperpolarising current in addition to $\mathrm{K}_{\text {ATP }}$ channels. To test this hypothesis we measured wholecell $\mathrm{K}^{+}$currents (Fig. 5a,b). In WT beta cells stimulated with $15 \mathrm{mmol} / 1$ glucose, application of $1 \mathrm{mmol} / 1 \mathrm{H}_{2} \mathrm{O}_{2}$ evoked a marked increase in $\mathrm{K}^{+}$current that was largely inhibitable by tolbutamide $(100 \mu \mathrm{mol} / 1, n=8, p \leq 0.001)$. However, a small component resistant to the $\mathrm{K}_{\text {ATP }}$ channel blocker was also identified. This component was sensitive to paxillin $(10 \mu \mathrm{mol} / 1, n=4, p \leq 0.01)$, a blocker of BK channels [23]. By contrast, in BK-KO beta cells the current 

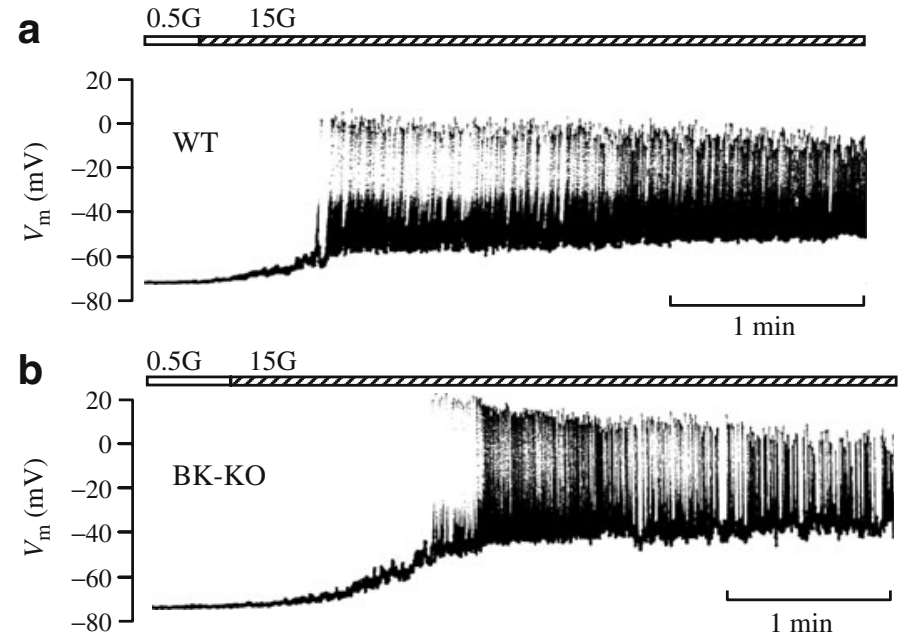

\section{C}

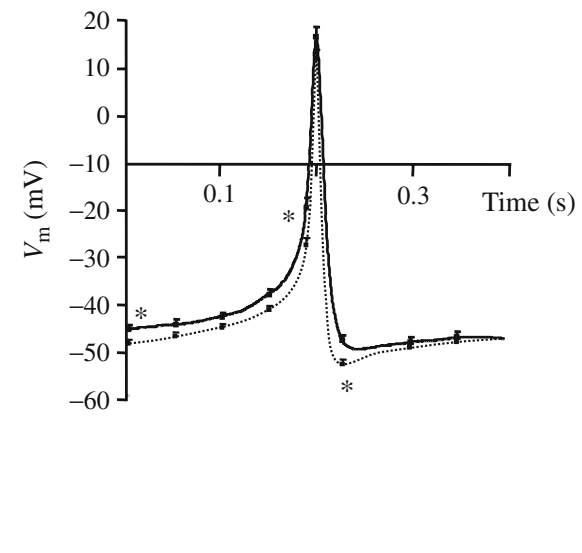

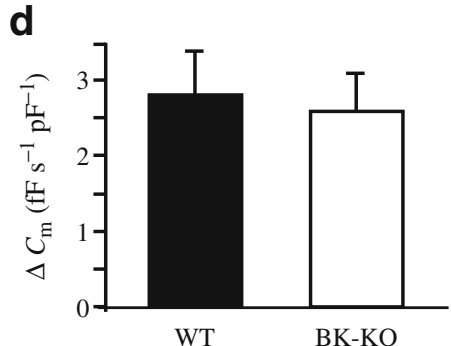

Fig. 4 Electrical activity, exocytosis and cell viability. a,b The effect of glucose stimulation on electrical activity is similar in (a) WT and (b) BKKO beta cells. Glucose concentrations are indicated by the horizontal bars, with the white section indicating glucose $0.5 \mathrm{mmol} / 1$ and the hatched section indicating glucose $15 \mathrm{mmol} / \mathrm{l}$. Experiments were performed in the perforated-patch configuration. The recordings are representative of 12 experiments with each genotype. c Comparison of glucose-induced action potentials recorded from WT (dotted line) and BK-KO (solid line) beta cells. The traces show the average of 12

evoked by $1 \mathrm{mmol} / 1 \mathrm{H}_{2} \mathrm{O}_{2}$ was significantly smaller and completely abolished by $100 \mu \mathrm{mol} / \mathrm{l}$ tolbutamide $(n=4$, $p \leq 0.001)$. Data are summarised in Fig. 5c. These results demonstrate that current through $\mathrm{BK}$ channels contributes to the $\mathrm{H}_{2} \mathrm{O}_{2}$-induced hyperpolarisation of pancreatic beta cells. As, for other tissues, activation of BK current has been shown to be an important mechanism to reduce ROSinduced cell damage [24], we tested whether genetic deletion or pharmacological inhibition of BK channels affects the rate of apoptosis in response to $\mathrm{H}_{2} \mathrm{O}_{2}$. Figure $5 \mathrm{~d}$ shows that the increase in the fraction of apoptotic islet cells provoked by 10,25 and $100 \mu \mathrm{mol} / 1 \mathrm{H}_{2} \mathrm{O}_{2}$, respectively, was significantly lower in WT compared with BKKO cells $(n=3)$, suggesting that activation of BK channels is part of the cellular defence mechanism to maintain cell viability under conditions of elevated oxidative stress. To test whether BK channel blockade with iberiotoxin could mimic the effect of BK-KO, WT islet cells were incubated for $36 \mathrm{~h}$ with $100 \mathrm{nmol} / \mathrm{l}$ iberiotoxin prior to $\mathrm{H}_{2} \mathrm{O}_{2}$ application. In this series of experiments the pro-apoptotic

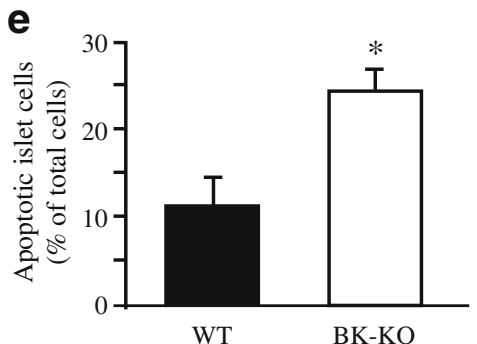

experiments per genotype. d Exocytosis was determined as the increase in $C_{\mathrm{m}}$ immediately after establishing the standard whole-cell configuration (WT $n=14$; BK-KO $n=13$ ). The cells were dialysed with pipette solution containing $10 \mu \mathrm{mol} / 1 \mathrm{Ca}^{2+}$. e BK-KO mice have an increased number of apoptotic islet cells. Apoptotic cells were detected by determination of activated caspase 3. Isolated islet cells were analysed after overnight culture in RPMI medium $(11.1 \mathrm{mmol} / \mathrm{l}$ glucose $)$. The data were obtained from four different preparations per genotype. ${ }^{*} p \leq 0.05$

action of $100 \mu \mathrm{mol} / 1 \mathrm{H}_{2} \mathrm{O}_{2}$ was markedly enhanced in iberiotoxin-treated cells vs controls ( $n=3$, Fig. 5 e).

\section{Discussion}

BK channels are $\mathrm{Ca}^{2+}$ - and voltage-regulated $\mathrm{K}^{+}$channels that occur in most tissues of the body. In excitable cells of endocrine, nervous and vascular systems BK channels link intracellular signalling to electrical activity [16, 25-27].

In 1996 cDNA of the Slol gene that encodes the poreforming alpha subunit of BK channels was identified and characterised in human pancreatic islets [28]. In the present study we detected two splice variants of the alpha subunit, Zero and Strex, in single beta cells (Fig. 1d). In human beta cells, BK current has been reported to account for a significant part of $\mathrm{K}_{\mathrm{v}}$ currents and pharmacological inhibition of BK channels influenced by insulin secretion [15]. However, the significance of these observations for glycaemic control of the whole organism remains unclear. The 
a WT

$15 \mathrm{G}, 1 \mathrm{mmol} / 1 \mathrm{H}_{2} \mathrm{O}_{2}$

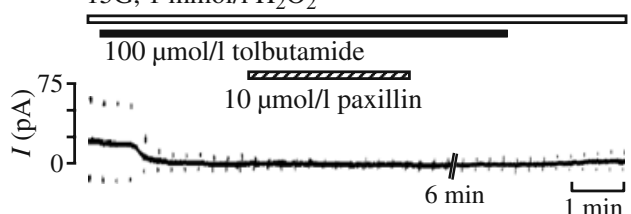

C

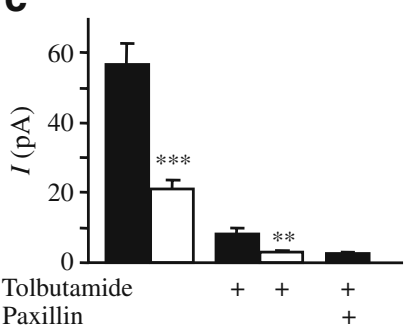

b

BK-KO

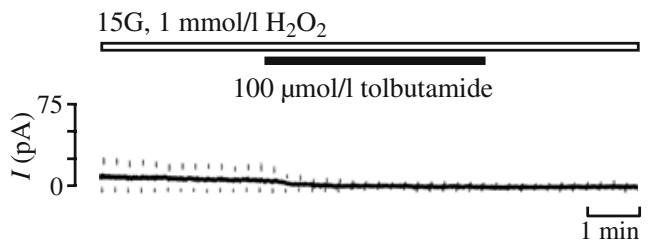

Fig. 5 Influence of $\mathrm{H}_{2} \mathrm{O}_{2}$ on ion currents and cell viability in WT and BK-KO islet cells. a, b The $\mathrm{K}^{+}$current induced by application of $\mathrm{H}_{2} \mathrm{O}_{2}$ was composed of $\mathrm{K}_{\text {ATP }}$ and $\mathrm{BK}$ current. In the perforated-patch configuration glucose-stimulated beta cells ( $15 \mathrm{mmol} / \mathrm{l}$ glucose) were exposed to $1 \mathrm{mmol} / 1 \mathrm{H}_{2} \mathrm{O}_{2}$ (indicated by the white horizontal bar). In cells from WT islets the current evoked by $10 \mathrm{mV}$ depolarising voltage steps from the holding potential of $-70 \mathrm{mV}$ was inhibited by tolbutamide ( $100 \mu \mathrm{mol} / \mathrm{l}$; indicated by the black horizontal bar) except for a small component that was sensitive to the BK channel inhibitor paxillin $(10 \mu \mathrm{mol} / \mathrm{l}$; indicated by the hatched horizontal bar). b In cells from BK-KO islets the current was completely blocked by tolbutamide. $\mathbf{c}$ The diagram shows the analysis of the experiments described in $\mathbf{a}$, b; black bars, WT; white bars, BK-KO. The number of experiments for $\mathrm{H}_{2} \mathrm{O}_{2}$-induced increase in $\mathrm{K}^{+}$current was 13 for WT and seven for BK-KO beta cells. The effect of tolbutamide was tested in eight WT and four BK-KO cells, respectively. Paxillin was given in addition to the sulfonylurea in four experiments with WT cells. d The fraction of caspase-3-positive islet cells after $1 \mathrm{~h}$ incubation with different concentrations of $\mathrm{H}_{2} \mathrm{O}_{2}(10,25$ and $100 \mu \mathrm{mol} / 1$, respectively) was significantly higher in $\mathrm{BK}$ channel-deficient islet cells. The experiments were performed after overnight culture of dispersed islet cells in RPMI medium (G11.1). The diagram summarises the data obtained from three separate preparations per genotype. Black bars, WT; white bars, BK-KO. e Islets of WT mice were incubated in RPMI medium or in medium supplemented with $100 \mathrm{nmol} / \mathrm{l}$ iberiotoxin for $36 \mathrm{~h}$. For an additional $6 \mathrm{~h} \mathrm{H}_{2} \mathrm{O}_{2}(25$ or $100 \mu \mathrm{mol} / \mathrm{l})$ was added and the fraction of apoptotic cells was determined by TUNEL staining $(n=$ 3). Black bars, WT; white bars, WT + iberiotoxin. ${ }^{*} p \leq 0.05$, ${ }^{* *} p \leq$ $0.01, * * * p \leq 0.001 \mathrm{WT}$ vs BK-KO or WT vs iberiotoxin-treated WT cells

is very unlikely as the frequency of $\mathrm{Ca}^{2+}$ oscillations, which is controlled by $V_{\mathrm{m}}$, is similar in both genotypes. Our experiments show that inhibition or $\mathrm{KO}$ of $\mathrm{BK}$ channels does not influence bulk $\left[\mathrm{Ca}^{2+}\right]_{\mathrm{c}}$ (Fig. 3). However, BK channels might participate in regulation of the local $\mathrm{Ca}^{2+}$ concentration which is decisive for control of the exocytotic machinery [29]. The existence of sub-membrane $\mathrm{Ca}^{2+}$ gradients with high $\mathrm{Ca}^{2+}$ concentration directly beneath the plasma membrane has been shown for primary beta cells by Quesada et al. [30]. In addition, the loss of the after-hyperpolarisation might leave more $\mathrm{Ca}^{2+}$ channels in the inactivated state thereby reducing the number of channels that could be recruited by the following action potential. Such subtle changes in $\mathrm{Ca}^{2+}$ influx are most likely too small to change bulk $\left[\mathrm{Ca}^{2+}\right]_{\mathrm{c}}$, but could alter exocytosis of insulin-containing granules by diminishing $\left[\mathrm{Ca}^{2+}\right]$ in sub-membrane domains.

BK channels are known to participate in the control of cell mass. For various tumour cell lines it has been shown that BK channel activity modulates proliferation and cell death [19, 31]. Our data provide the first evidence that BK channel ablation affects cell viability in pancreatic islets 
(Fig. 4e). Compared with WT islet cells, the fraction of apoptotic cells was more than doubled in BK-KO cells. Importantly, similar changes occurred in WT cells after incubation with iberiotoxin. This indicates that alterations in cell viability are not a by-product of the genetic manipulation but are directly linked to loss of BK channel function. The mechanisms by which BK channels modulate signalling pathways determining cell death are not yet resolved. Mitochondrial BK channels have been reported to interfere with $\mathrm{Ca}^{2+}$ sequestration [32] and the mitochondrial permeability transition pore $[33,34]$. However, the fact that the non-membrane-permeant peptide iberiotoxin induces similar effects as BK-KO argues against an involvement of mitochondrial BK channels. It is well known that, in several cell types, plasma-membrane-located $\mathrm{K}^{+}$channels contribute to the regulation of apoptosis. Mostly, inhibition of $\mathrm{K}^{+}$channels reduces apoptosis but the opposite has also been reported [35, 36]. There are several studies demonstrating that pharmacological or genetic elimination of $\mathrm{K}_{\mathrm{ATP}}$ channels increases apoptotic cell death [22, 37]. Our results suggest that the same holds true for conditions with reduced BK channel activity.

As neither insulin content nor high $\mathrm{K}^{+}$-induced insulin secretion was diminished in $\mathrm{BK}-\mathrm{KO}$ islets, the proapoptotic effect of BK channel elimination is unlikely to contribute to the impaired secretory response induced by glucose stimulation. However, our study demonstrates that BK channels are important regulators of beta cell viability under conditions of increased oxidative stress (Fig. 5). It is well known that beta cells are extremely vulnerable to ROS due to their poor antioxidant defence mechanisms [38]. Consequently, oxidative stress severely impairs beta cell function and viability [39-42]. BK channels have been reported to be modulated by $\mathrm{H}_{2} \mathrm{O}_{2}$ [43]. Our data show that besides $\mathrm{K}_{\text {ATP }}$ channels [44], activation of $\mathrm{BK}$ channels contributes to the hyperpolarising current elicited in the presence of $\mathrm{H}_{2} \mathrm{O}_{2}$ (Fig. 5a, b) which might serve as a protective mechanism to avoid $\mathrm{Ca}^{2+}$ overload of the cells. At present we cannot rule out that knockout of BK channels induces changes secondary to channel deletion. As the paxillin-sensitive component of the $\mathrm{H}_{2} \mathrm{O}_{2}$-induced $\mathrm{K}^{+}$ current is much smaller than the difference between WT and $\mathrm{BK}-\mathrm{KO}$ beta cells, expression of additional $\mathrm{K}^{+}$currents might be affected. So far such interactions have not been described for pancreatic beta cells but are reported for the cochlea, where BK-KO leads to disappearance of Kv7.4 channels in outer hair cells [45]. Importantly, compared with WT controls the susceptibility to $\mathrm{H}_{2} \mathrm{O}_{2}$-mediated apoptosis was markedly elevated in islet cells derived from BK-KO mice or in iberiotoxin-treated WT cells (Fig. 5d,e). This suggests that activation of BK channels contributes to the defence mechanisms protecting beta cells against oxidative cell damage. In agreement with our results it was demonstrated for hippocampal neurons that pharmacological BK channel inhibition aggravates hypoxia-induced cell death [24]. It is noteworthy that inhibition of BK or $\mathrm{K}_{\mathrm{ATP}}$ channels increases the rate of basal apoptosis but exerts contrary effects on the sensitivity of beta cells to oxidative stress. The protective effect of $\mathrm{K}_{\text {ATP }}$ channel inhibition is caused by an upregulation of antioxidant enzymes that depends on alterations in intracellular $\mathrm{Ca}^{2+}$ sequestration [22]. As limitation of BK channel activity does not coincide with protection against ROS-induced cell death, this indicates that modulation of antioxidative defence mechanisms is particularly related to $\mathrm{K}_{\mathrm{ATP}}$ channels and not generally induced by $\mathrm{K}^{+}$channel inhibition.

In summary, our investigations show that BK channels play a role in glucose homeostasis and affect the susceptibility of pancreatic beta cells to oxidative stress.

Acknowledgements We thank I. Breuning for skilful technical assistance. This work was supported by grants from the DFG Dr225/ 6-3 (G. Drews), DU425/1-2 (M. Düfer) and the Wellcome Trust (M. J. Shipston and P. Ruth). Parts of this study have been published in abstract form (Diabetologia [2004] 47(Suppl 1):208).

Duality of interest The authors declare that there is no duality of interest associated with this manuscript.

\section{References}

1. MacDonald PE, Wheeler MB (2003) Voltage-dependent $\mathrm{K}^{+}$ channels in pancreatic beta cells: role, regulation and potential as therapeutic targets. Diabetologia 46:1046-1062

2. Tamarina NA, Wang Y, Mariotto L et al (2003) Small-conductance calcium-activated $\mathrm{K}^{+}$channels are expressed in pancreatic islets and regulate glucose responses. Diabetes 52:2000-2006

3. Düfer M, Gier B, Wolpers D, Krippeit-Drews P, Ruth P, Drews G (2009) Enhanced glucose tolerance by SK4 channel inhibition in pancreatic beta-cells. Diabetes 58:1835-1843

4. Smith PA, Bokvist K, Arkhammar P, Berggren PO, Rorsman P (1990) Delayed rectifying and calcium-activated $\mathrm{K}^{+}$channels and their significance for action potential repolarization in mouse pancreatic beta-cells. J Gen Physiol 95:1041-1059

5. Cook DL, Ikeuchi M, Fujimoto WY (1984) Lowering of pHi inhibits $\mathrm{Ca}^{2+}$-activated $\mathrm{K}^{+}$channels in pancreatic B cells. Nature 311:269-271

6. Ribalet B, Eddlestone GT, Ciani S (1988) Metabolic regulation of the $\mathrm{K}_{\mathrm{ATP}}$ and a maxi-K $\mathrm{K}_{\mathrm{V}}$ channel in the insulin-secreting RINm5F cell. J Gen Physiol 92:219-237

7. Henquin JC (1990) Role of voltage- and $\mathrm{Ca}^{2+}$-dependent $\mathrm{K}^{+}$ channels in the control of glucose-induced electrical activity in pancreatic B cells. Pflügers Arch 416:568-572

8. Kukuljan M, Goncalves AA, Atwater I (1991) Charybdotoxinsensitive $\mathrm{K}_{\mathrm{Ca}}$ channel is not involved in glucose-induced electrical activity in pancreatic beta-cells. J Membr Biol 119:187-195

9. Krippeit-Drews P, Düfer M, Drews G (2000) Parallel oscillations of intracellular calcium activity and mitochondrial membrane potential in mouse pancreatic B cells. Biochem Biophys Res Commun 267:179-183

10. Rolland JF, Henquin JC, Gilon P (2002) Feedback control of the ATP-sensitive $\mathrm{K}^{+}$current by cytosolic $\mathrm{Ca}^{2+}$ contributes to 
oscillations of the membrane potential in pancreatic beta-cells. Diabetes 51:376-384

11. Haspel D, Krippeit-Drews P, Aguilar-Bryan L, Bryan J, Drews G, Düfer M (2005) Crosstalk between membrane potential and cytosolic $\mathrm{Ca}^{2+}$ concentration in beta cells from $\mathrm{Sur}^{-/-}$mice. Diabetologia 48:913-921

12. Ravier MA, Nenquin M, Miki T, Seino S, Henquin JC (2009) Glucose controls cytosolic $\mathrm{Ca}^{2+}$ and insulin secretion in mouse islets lacking adenosine triphosphate-sensitive $\mathrm{K}^{+}$channels owing to a knockout of the pore-forming subunit Kir6.2. Endocrinology 150:33-45

13. Göpel SO, Kanno T, Barg S et al (1999) Activation of $\mathrm{Ca}^{2+}$ dependent $\mathrm{K}^{+}$channels contributes to rhythmic firing of action potentials in mouse pancreatic beta cells. J Gen Physiol 114:759770

14. Zhang M, Houamed K, Kupershmidt S, Roden D, Satin LS (2005) Pharmacological properties and functional role of $\mathrm{K}_{\text {slow }}$ current in mouse pancreatic beta-cells: SK channels contribute to $\mathrm{K}_{\text {slow }}$ tail current and modulate insulin secretion. J Gen Physiol 126:353363

15. Braun M, Ramracheya R, Bengtsson M et al (2008) Voltage-gated ion channels in human pancreatic beta-cells: electrophysiological characterization and role in insulin secretion. Diabetes 57:16181628

16. Sausbier $\mathrm{M}, \mathrm{Hu} \mathrm{H}$, Arntz $\mathrm{C}$ et al (2004) Cerebellar ataxia and Purkinje cell dysfunction caused by $\mathrm{Ca}^{2+}$-activated $\mathrm{K}^{+}$channel deficiency. Proc Natl Acad Sci USA 101:9474-9478

17. Barg S, Galvanovskis J, Göpel SO, Rorsman P, Eliasson L (2000) Tight coupling between electrical activity and exocytosis in mouse glucagon-secreting alpha-cells. Diabetes 49:1500-1510

18. Grynkiewicz G, Poenie M, Tsien RY (1985) A new generation of $\mathrm{Ca}^{2+}$ indicators with greatly improved fluorescence properties. J Biol Chem 260:3440-3450

19. Weaver AK, Liu X, Sontheimer H (2004) Role for calciumactivated potassium channels (BK) in growth control of human malignant glioma cells. J Neurosci Res 78:224-234

20. Krippeit-Drews $\mathrm{P}$, Krämer C, Welker S, Lang F, Ammon HP, Drews $\mathrm{G}$ (1999) Interference of $\mathrm{H}_{2} \mathrm{O}_{2}$ with stimulus-secretion coupling in mouse pancreatic beta-cells. J Physiol 514:471-481

21. Drews G, Krämer C, Krippeit-Drews P (2000) Dual effect of NO on $\mathrm{K}_{\mathrm{ATP}}{ }^{+}$current of mouse pancreatic B cells: stimulation by deenergizing mitochondria and inhibition by direct interaction with the channel. Biochim Biophys Acta 1464:62-68

22. Gier B, Krippeit-Drews P, Aguilar-Bryan L, Bryan J, Düfer M, Drews $G$ (2009) Suppression of $K_{\text {ATP }}$ channel activity protects murine pancreatic beta cells against oxidative stress. J Clin Invest 119:3246-3256

23. Knaus HG, McManus OB, Lee SH et al (1994) Tremorgenic indole alkaloids potently inhibit smooth muscle high-conductance calcium-activated potassium channels. Biochemistry 33:58195828

24. Rundén-Pran E, Haug FM, Storm JF, Ottersen OP (2002) BK channel activity determines the extent of cell degeneration after oxygen and glucose deprivation: a study in organotypical hippocampal slice cultures. Neuroscience 112:277-288

25. Robitaille R, Charlton MP (1992) Presynaptic calcium signals and transmitter release are modulated by calcium-activated potassium channels. J Neurosci 12:297-305

26. Brenner R, Peréz GJ, Bonev AD et al (2000) Vasoregulation by the betal subunit of the calcium-activated potassium channel. Nature 407:870-876

27. Yang MJ, Wang F, Wang JH et al (2010) PI3-k integrates the effects of insulin and leptin on large-conductance $\mathrm{Ca}^{2+}$-activated $\mathrm{K}^{+}$channels in neuropeptide $\mathrm{Y}$ neurons of the hypothalamic arcuate nucleus. Am J Physiol Endocrinol Metab 298:E193-E201
28. Ferrer J, Wasson J, Salkoff L, Permutt MA (1996) Cloning of human pancreatic islet large conductance $\mathrm{Ca}^{2+}$-activated $\mathrm{K}^{+}$ channel (hSlo) cDNAs: evidence for high levels of expression in pancreatic islets and identification of a flanking genetic marker. Diabetologia 39:891-898

29. Bokvist K, Eliasson L, Ammälä C, Renström E, Rorsman $P$ (1995) Co-localization of L-type $\mathrm{Ca}^{2+}$ channels and insulincontaining secretory granules and its significance for the initiation of exocytosis in mouse pancreatic B cells. EMBO J 14:50-57

30. Quesada I, Martín F, Soria B (2000) Nutrient modulation of polarized and sustained submembrane $\mathrm{Ca}^{2+}$ microgradients in mouse pancreatic islet cells. J Physiol 525:159-167

31. Meera P, Wallner M, Toro L (2000) A neuronal beta subunit (KCNMB4) makes the large conductance, voltage- and $\mathrm{Ca}^{2+}$. activated $\mathrm{K}^{+}$channel resistant to charybdotoxin and iberiotoxin. Proc Natl Acad Sci USA 97:5562-5567

32. Cheranov SY, Jaggar JH (2004) Mitochondrial modulation of $\mathrm{Ca}^{2+}$ sparks and transient $\mathrm{K}_{\mathrm{Ca}}$ currents in smooth muscle cells of rat cerebral arteries. J Physiol 556:755-771

33. Stowe DF, Aldakkak M, Camara AK et al (2006) Cardiac mitochondrial preconditioning by big $\mathrm{Ca}^{2+}$-sensitive $\mathrm{K}^{+}$channel opening requires superoxide radical generation. Am J Physiol Heart Circ Physiol 290:H434-H440

34. Cheng Y, Gu XQ, Bednarczyk P, Wiedemann FR, Haddad GG, Siemen D (2008) Hypoxia increases activity of the BK-channel in the inner mitochondrial membrane and reduces activity of the permeability transition pore. Cell Physiol Biochem 22:127-136

35. Lang F, Huber SM, Szabo I, Gulbins E (2007) Plasma membrane ion channels in suicidal cell death. Arch Biochem Biophys 462:189-194

36. Patel AJ, Lazdunski M (2004) The $2 \mathrm{P}$-domain $\mathrm{K}^{+}$channels: role in apoptosis and tumorigenesis. Pflügers Arch 448:261-273

37. Miki T, Tashiro F, Iwanaga $T$ et al (1997) Abnormalities of pancreatic islets by targeted expression of a dominant-negative $\mathrm{K}_{\mathrm{ATP}}$ channel. Proc Natl Acad Sci USA 22:11969-11973

38. Lenzen S, Drinkgern J, Tiedge M (1996) Low antioxidant enzyme gene expression in pancreatic islets compared with various other mouse tissues. Free Radic Biol Med 20:463-466

39. Tsuura Y, Ishida H, Hayashi S, Sakamoto K, Horie M, Seino Y (1994) Nitric oxide opens ATP-sensitive $\mathrm{K}^{+}$channels through suppression of phosphofructokinase activity and inhibits glucoseinduced insulin release in pancreatic beta cells. J Gen Physiol 104:1079-1098

40. Drews G, Krämer C, Düfer M, Krippeit-Drews P (2000) Contrasting effects of alloxan on islets and single mouse pancreatic beta-cells. Biochem J 352:389-397

41. Di Matteo MA, Loweth AC, Thomas S et al (1997) Superoxide, nitric oxide, peroxynitrite and cytokine combinations all cause functional impairment and morphological changes in rat islets of Langerhans and insulin secreting cell lines, but dictate cell death by different mechanisms. Apoptosis 2:164-177

42. Li LX, Skorpen F, Egeberg K, Jørgensen IH, Grill V (2001) Uncoupling protein-2 participates in cellular defense against oxidative stress in clonal beta-cells. Biochem Biophys Res Commun 282:273-277

43. Tang XD, Garcia ML, Heinemann SH, Hoshi T (2004) Reactive oxygen species impair Slo1 BK channel function by altering cysteine-mediated calcium sensing. Nat Struct Mol Biol 11:171-178

44. Krippeit-Drews P, Lang F, Häussinger D, Drews G (1994) $\mathrm{H}_{2} \mathrm{O}_{2}$ induced hyperpolarization of pancreatic $\mathrm{B}$ cells. Pflügers Arch 426:552-554

45. Rüttiger L, Sausbier M, Zimmermann U et al (2004) Deletion of the $\mathrm{Ca}^{2+}$-activated potassium (BK) alpha-subunit but not the BKbeta1-subunit leads to progressive hearing loss. Proc Natl Acad Sci USA 101:12922-12927 